Hydrology and Earth System Sciences, 6(6), 983-989 (2002) C C EGS

\title{
Nearshore circulation revealed by wastewater discharge from a submarine outfall, Aveiro Coast, Portugal
}

\author{
J. Figueiredo da Silva ${ }^{1}$, R.W. Duck ${ }^{2}$, T.S. Hopkins ${ }^{3}$ and J.M. Anderson ${ }^{4}$ \\ ${ }^{1}$ Departamento de Ambiente e Ordenamento, Universidade de Aveiro, 3810-193 Aveiro, Portugal \\ ${ }^{2}$ Department of Geography, University of Dundee, Scotland \\ ${ }^{3}$ Department of Marine Earth and Atmospheric Sciences, North Carolina State University, Raleigh, USA \\ ${ }^{4}$ Division of Electronic Engineering and Physics, University of Dundee, Scotland \\ Email for corresponding author: jfs@ua.pt
}

\begin{abstract}
The morphological and climatic conditions of the Atlantic coast of northern Portugal result in a prevailing upwelling circulation over the continental shelf. A submarine outfall releases wastewater into the ocean c. $3 \mathrm{~km}$ directly offshore (at $\sim 16 \mathrm{~m}$ water depth) from S. Jacinto, 5 $\mathrm{km}$ to the north of the inlet to the estuarine coastal lagoon system of the Ria de Aveiro. The buoyant plume has a distinctive reddish brown colour and is clearly visible at the water surface. The transport and dispersion of the plume was monitored by airborne photography and by in situ water sampling. Results revealed the surface currents present and water mass fronts in the nearshore zone of the Aveiro coast. During the spring and summer, the plume was not transported offshore in the manner expected by the upwelling shelf circulation. Instead, it was commonly observed to be transported alongshore with the prevailing southerly circulation or with an onshore component. The transport to the south caused the outfall plume to interact with the circulation associated with the tidal currents generated in the inlet channel to the Ria de Aveiro. The observations suggest that the trophic status of the Ria de Aveiro is unlikely to change because of the operation of the submarine outfall. Furthermore, this study demonstrates how simple observations of wastewater discharge from a submarine outfall can be used to improve understanding of nearshore circulation.
\end{abstract}

Keywords: water circulation, upwelling, ocean outfall, remote sensing, eutrophication, Ria de Aveiro

\section{Introduction}

In Portugal, European Community legislation (Council Directive 91/271/EEC concerning urban waste-water treatment) has resulted in the expansion of municipal sanitation systems several of which result in final discharge to the sea. The study of wastewater discharges can, however, help to provide valuable information concerning nearshore circulation patterns. This paper describes how a study of one such discharge from a submarine outfall located on the Aveiro coast of northern Portugal has enabled an improved understanding of the nearshore circulation system.

The Atlantic coast of Portugal, to the south of $41^{\circ} \mathrm{N}$, follows an approximately straight line trending $15^{\circ}$ to the east of north. The continental shelf has a relatively flat surface down to a depth of $180 \mathrm{~m}$ at $c .40 \mathrm{~km}$ offshore. The nearly linear coast of Aveiro is interrupted locally by two breakwaters forming the inlet channel to the coastal lagoon system of the Ria de Aveiro (Fig. 1). The inner limit of the nearshore zone corresponds to an alongshore sand-bar that, in front of the inlet channel, extends to the southwest bordering the external ebb channel of the Ria de Aveiro. Seaward of the sand-bar, the slope of the sea bed is steep down to a water depth of $12 \mathrm{~m}$, corresponding to the outer limit of the upper shoreface, located $1 \mathrm{~km}$ from the beach. The bottom slope then decreases to a water depth of $15 \mathrm{~m}$ at c. $3 \mathrm{~km}$ from the beach. Offshore, a marked increase of slope is observed. The same type of shoreface profile was observed to the south of the inlet channel by Ferreira (1993), where the steeper slope extends down to a water depth of $30 \mathrm{~m}$, corresponding to the outer limit of the nearshore.

Over the shelf, wind driven currents generate either an upwelling circulation (northwesterly winds) or a downwelling circulation (southwesterly winds). Upwelling circulation is a frequent phenomenon on the Portuguese 


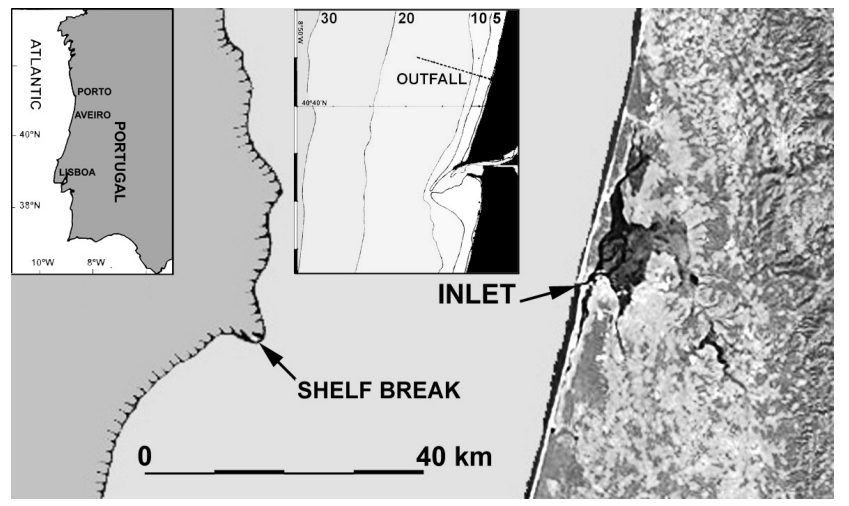

Fig.1. Map of the study area showing the continental shelf (light grey) and the Ria de Aveiro coastal area (note inlet channel) as observed in Landsat imagery. Left inset gives location in Portugal. Right inset shows the shoreface bathymetry and the location of the submarine outfall.

continental shelf during the summer months, in which surface currents transport upwelled water offshore, forming cold filaments. Haynes et al. (1993) discussed the mechanisms of formation, development and variability of these filaments. The upwelling is the result of the largescale wind field generated by the pressure difference between the high pressure over the Atlantic relative to the low pressure over Iberia. This atmospheric condition is quite persistent from May to September but varies in strength and duration interannually.

Over the shelf at the latitude of Aveiro, this meteorological condition generates winds from the northwestern quadrant. Over the mid and outer shelf, the offshore component of the transport in the surface Ekman layer generates a conventional coastal upwelling circulation that results in a lowering of the water surface and a compensating onshore ascent of deeper water. As a result, sub-surface Central North Atlantic Water is present near the coast (Álvarez-Salgado et al., 2000) and the surface temperature is up to $5^{\circ} \mathrm{C}$ lower than that observed offshore. The upwelled water brings new nutrients to the surface, which promote the growth of phytoplankton, resulting in pigment structures that were identified by satellite images (Sousa and Bricaud, 1992).

In the nearshore zone, the circulation response to the winds from the northwestern quadrant is importantly different (Niedoroda et al., 1984; Hopkins and Swoboda, 1986). As the wind-mixing depth begins to 'feel' the bottom, the net surface transport becomes more downwind and, with the additional component of surface wave transport, generates a surface convergence at the coast and a downwelling circulation pattern. After an upwelling event, the heating of the surface layer by solar radiation generates thermal stratification and increases the response of the surface layer to wind forcing (Gómez-Gesteira et al., 2001). Towards the end of the upwelling season, a northward current in the nearshore zone was identified by Sordo et al. (2001), while over the shelf the southward jet was still present. Thus, the nearshore circulation is strongly dependent on changes in wind and wave conditions, which greatly complicate the dispersion of buoyant effluents within the nearshore region.

During autumn and winter, the area is influenced by the mid latitude depressions, moving to the east and causing strong southwesterly winds, which then veer clockwise to the northwest as the atmospheric pressure rises over the Atlantic. When the wind from the south is strong and of sufficient duration, a downwelling circulation sets up over the shelf, with a northward surface current over the entire shelf (Frouin et al., 1990). However, these downwelling wind events, occurring primarily in the autumn and winter, are much less frequent than the upwelling winds, which occur at any time but most persistently in the spring and summer.

The Aveiro coast is exposed to a swell generated by north Atlantic storms, which can have a different direction than the shorter-period local wind waves. From April to September, waves with a mean significant height of $1.5 \mathrm{~m}$ and period of $\sim 6 \mathrm{~s}$ approach the coast from the northwest $\left(300^{\circ}\right)$. From October to March, large waves are common and the mean significant height increases to $2.4 \mathrm{~m}$ and period to $\sim 8 \mathrm{~s}$ (Capitão et al., 1999).

Tides observed in the inlet channel of the Ria de Aveiro are regular semi-diurnal with a mean amplitude of $c .2 \mathrm{~m}$ and the consequent periodic flow can be a minor forcing mechanism in an open coastal area. However, on the Aveiro coast, interaction between the wind/wave driven currents and the tidal currents into and out of the ria is fundamental to the water circulation in the area (Silva et al., 2001). Airborne remote sensing observations, together with surface sampling and measurements of temperature and salinity, have revealed a complex water exchange system during the tidal cycle. During the flood tide, the littoral drift from the north is diverted eastwards into the inlet channel on its northern side. On the south side, a smaller flow of warmer water returns landward into the channel from the south. A clear V-shaped foam line delimits these different water masses. During the ebb tide, as the strength of the ebb tidal currents increases, the waters leaving the channel become progressively more turbid and a mushroom-shaped plume, projecting either alongshore to the south or offshore, begins to develop. The ocean area affected by this exchange extends a few kilometres offshore (Silva et al., 2001).

The hydrodynamic conditions described above were judged by the Portuguese authorities to be favourable for the location of a submarine outfall. The expected dispersion of wastewater directed seaward would be a low cost option 
for reducing the organic loading of the inland waters. Thus, a regional sewer system is being constructed progressively from the submarine outfall (Fig. 1) to the sewage collectors of the municipalities bordering the lagoon of the Ria de Aveiro and also to a large pulp plant, which presently (2002) contributes $90 \%$ of the total flow discharged. The submarine outfall releases wastewater with secondary level treatment, through a multiport diffuser, into the ocean $3 \mathrm{~km}$ directly offshore (at $\sim 16 \mathrm{~m}$ water depth) from S. Jacinto, $5 \mathrm{~km}$ to the north of the inlet to the Ria de Aveiro. The buoyant plume has a distinctive reddish brown colour, due to the pulp wastewater, and is clearly visible at the water surface. The nutrient loads that will be transferred into the ocean represent a small portion of the total loading of the lagoon and correspond to a reduction of $15 \%$ for nitrogen $(\mathrm{N})$ and $26 \%$ for phosphorus (P) (Silva et al., 2002).

\section{Equipment and methods}

The plume discharged from the Aveiro coastal outfall was observed by aerial photography in combination with water sampling from a small vessel. The remote observations took place from a CESNA 152 aircraft flying at heights ranging from 700 to $1500 \mathrm{~m}$. The aircraft was stationed at S. Jacinto, close to the study area, which facilitated multiple flights, minimising time to target and maximising data acquisition time. Oblique aerial photography was carried out using standard $35 \mathrm{~mm}$ cameras fitted with $50 \mathrm{~mm}$ lenses loaded with 100 ASA natural colour positive film. Collection of surface water samples and measurements of salinity and temperature profiles (using a WTW Salinometer, Model LF340) were undertaken from a $5.5 \mathrm{~m}$ cabin cruiser fitted with a $40 \mathrm{hp}$ outboard engine. In the laboratory, samples were filtered through GF filters for the determination of suspended solids concentration and the light transmission characteristics of filtrates were determined by spectrophotometry. Profiles of the sea bed and acoustic signals from within the water column were obtained with a Furuno FE-6300 echo-sounder. During surveys, both the aircraft and boat positions were recorded every second by a Magellan GPS ProMARK X CM (mobile mode) and later downloaded into a PC and plotted in geographical coordinates.

\section{Transport and dispersion of the plume}

\section{SURFACE OBSERVATIONS}

Surface water samples, collected on 13 October 2001 from within the area of the plume, produced a brown residue on filtration (concentration $\sim 3 \mathrm{mg} \mathrm{l}^{-1}$ ). The filtered water absorbed more blue light (0.05-0.01 absorption units) in the wavelength range $310-450 \mathrm{~nm}$, compared with ocean water collected outside the limits of the plume. These characteristics of the plume water do not imply that the initial dilution, between the diffuser and the surface, is small. In fact, the maximum difference in salinity (observed on 2 September 2001) measured between outside the plume and within the plume waters was $0.3 \mathrm{psu}$, corresponding to $\sim 1 \%$ of wastewater mixed with seawater. The colour of the plume is due to the intense colour of pulp mill wastewater, which accounts for more than $90 \%$ of the flow discharged (c. $\left.0.7 \mathrm{~m}^{3} \mathrm{~s}^{-1}\right)$.

Another measurement, useful for the interpretation of aerial photographs, is the temperature field, which, during the dry season, can be the principal factor controlling variations in the stratification. Measurements made on 2 September 2001 showed both vertical and lateral variations in temperature. The vertical temperature decrease, from the surface to a depth of $7 \mathrm{~m}$, was $0.2-0.8^{\circ} \mathrm{C}$ (the salinity varied by less than $0.1 \mathrm{psu}$ ), indicating some thermal stratification in the water column during calm summer weather. Temperature also decreased by $0.4-1.1^{\circ} \mathrm{C}$ between the buoy marking the diffuser (17 m depth) and the onshore zone (13 m depth). The temperature measured within the effluent plume was typically lower $\left(0.4-2.0^{\circ} \mathrm{C}\right)$ than outside the plume. The observed density difference is small (less than $0.3 \mathrm{~kg} \mathrm{~m}^{-3}$ higher in the plume water) because lower salinity (0.1-0.3 psu) compensates for the lower temperature. This result was unexpected, as the wastewater has a temperature around $35^{\circ} \mathrm{C}$ so that the lower temperature in the plume suggests a reasonably large dilution $(>100 \times$ based on salinity), provided by the diffusers, with near bottom water that is colder than the surface waters. The thermal stratification can eventually lead to a situation in which the plume does not rise to the surface and so cannot be observed from the air. This probably occurred on 2 and 16 September 2001 when the echo-sounder detected a sound reflecting structure from the diffuser up to a depth of $\sim 7 \mathrm{~m}$.

\section{AIRBORNE OBSERVATIONS}

The airborne observations reveal the shape of the plume formed by the water discharged from the outfall while it is transported and dispersed. The identification of the plume is based on the difference in colour/transparency of the plume water, typically observed as a dark, reddish brown water mass, surrounded by clear ocean water, which is usually light blue. This difference in observed colour depends on the presence of dissolved and suspended substances in the top few metres of the water column. The 
true colour of water depends on the presence of dissolved substances, but the concentration of suspended materials, which have a specific colour, will also cause a change in the apparent colour of the water. In this case, the presence of suspended sediment, phytoplankton and solids from the wastewater discharge can cause differences in the observed colour of the water masses.

The airborne observations can be classified into two groups, based on the size and direction of development of the plume. On the late ebb to early flood tide of 21 September 2000 (light wind from west to northwest) and the mid flood tide of 1 September 2001 (light wind from north), the plume developed over the diffusers and dispersed to the east over a distance of $<1 \mathrm{~km}$ (Fig. 2). Observations repeated 1-2 hours later on the flood tides of each of these dates showed that the plume changed to a longer, narrower shape, and turned in direction to the south. Thus, the prevailing weather conditions were causing weak currents that were subject to changes related to the tidal or wind forcing. The presence of a sharp transition in water colour and of foam lines, trending along the coast onshore of the diffuser, indicates a surface convergence of warmer offshore water with more turbulent water closer onshore (Fig. 2b).

On the flood tides of 27 September 2000 and 8 September 2001 (Fig. 3), the plume took the form of an elongated, narrow band extending for $\sim 5 \mathrm{~km}$ to the south in the direction of the inlet channel. These periods of observation corresponded with moderate north or northwesterly winds generating a longshore flow from north to south. When the plume extended as far south as the zone immediately offshore from the inlet channel, tidal effects also became important. On 27 September 2000 (Fig. 3a) with the wind from the north-west, the plume was diverted to the east, into the ria, by the flood tidal current (spring tide). On 8 September 2001 (Fig 3b), with the wind from the north, the plume extended to a point offshore from the mouth of the inlet but was apparently not diverted eastwards by the flood current (neap tide). On 29 April 2001, with a stronger wind from the northwest to west, the plume advanced more than $3 \mathrm{~km}$ to the south (Fig. 4a). Five hours later in the day, when the wind was very strong from the north-west, the plume dispersed over a shorter distance to the south-east (Fig. 4b).

\section{Discussion and conclusions}

The above observations of the plume show that the flow in the surface layer responds within a few hours to changes in wind forcing. The shape and direction of the observed plume from the Aveiro coastal outfall also depends on the antecedent current speed and direction during the previous days. The oceanographic conditions prevailing on the sampling dates were established on the basis of the sea surface temperature decrease from the open ocean to near the coast (Fig. 5) and on the transport vectors for the surface layer over the coastal shelf (Fig. 6). The temperature profiles were obtained from the Multi-Channel Sea Surface Temperature (MCSST) graphics published daily by the US Naval Oceanographic Office (http://navo.navy.mil) for the Iberian zone. The surface transport vectors were calculated from the Ekman transport data for the grid cell centred on $40.5^{\circ} \mathrm{N}$ and $9.5^{\circ} \mathrm{W}$, obtained from the Pacific Fisheries Environmental Laboratory (http://las.pfeg.noaa.gov). The surface transport in shallow water was calculated on the assumption that it occurs at $\sim 45^{\circ}$ to the right of the wind direction.

The wind forcing, causing upwelling, was more persistent during the summer of 2000 than that of 2001, which explains the larger decrease in sea surface temperature observed in September 2000 (Fig. 5). However, on the dates of sampling in September 2000, the wind forcing was weaker than during the sampling in September 2001 (Fig. 6). For April 2001, the upwelling was not yet established (Fig. 5) and the wind forcing was variable (Fig. 6).

Persistent wind forcing from the north over the northern Portuguese continental shelf transports surface water offshore and so colder water from depth upwells near the coast. After the upwelling events, during periods of light winds, solar radiation creates a warm surface layer that responds rapidly to changes in local wind velocity. The observations of 27 September 2000 and 8 September 2001, in which the wastewater discharge was seen as a narrow, long, southward moving plume, show that wind is the dominant forcing agent and that tidal effects can be important near the inlet channel.

Nearshore, as water depth decreases, the interaction of swell waves with the shoaling bottom generates a turbulent water mass that is convergent on the shore. This onshore transport sustains a pressure gradient that blocks further onshore surface flow, as observed by the movement of the wastewater plume on 21 September 2000 and 1 September 2001. Consequently, at the interface between this mixed nearshore water mass and the waters further offshore, a distinct interface is marked by a foam line and an increase in turbidity nearshore (Fig. 2b).

During this investigation, covering the spring and summer situations, offshore transport of the wastewater plume was not observed at the surface as might have been expected by a simple upwelling shelf circulation. Commonly the transport was to the south, in the direction of the inlet channel, or with an onshore component. Impacts of the pollutants released are, therefore, to be anticipated in the nearshore waters and potentially within the lagoon. Under 


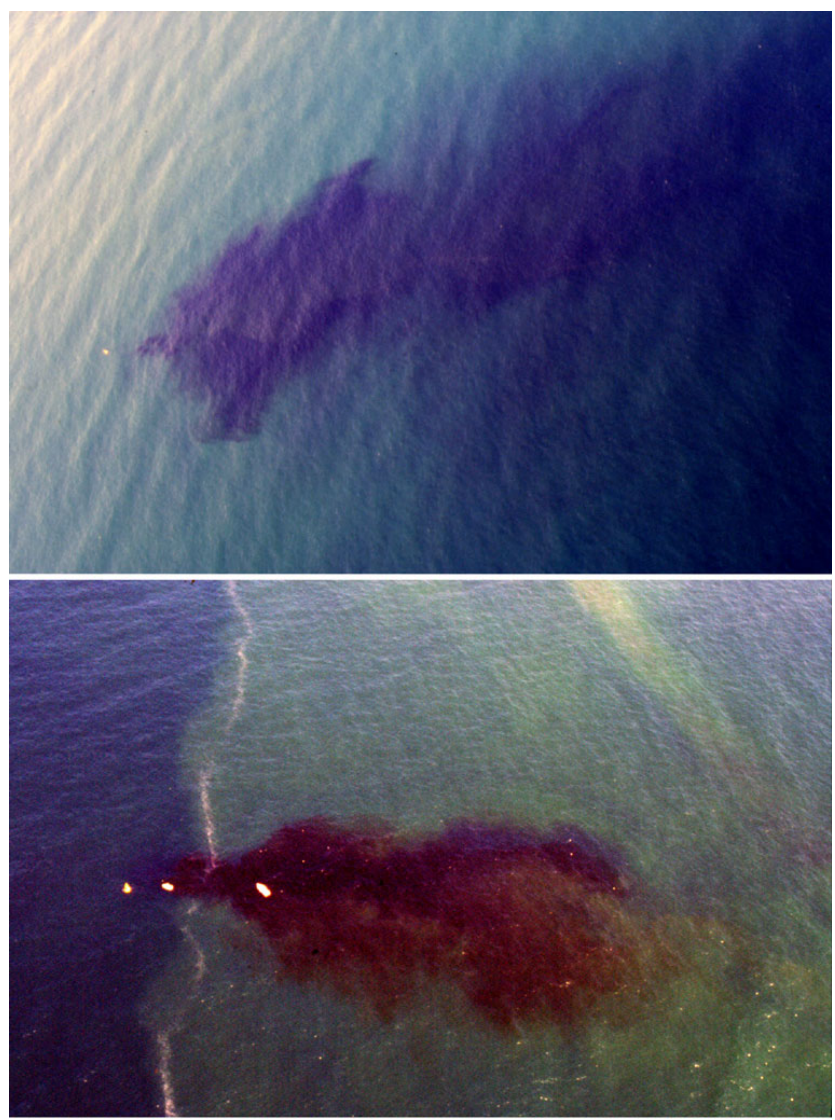

Fig. 2. a (upper panel). Oblique aerial photograph, obtained on 21 September 2000 (late ebb to early flood tide), showing the surface wastewater plume extending east/onshore (to the right) from the outfall. b (lower panel). Oblique aerial photograph, obtained on 1 September 2001 (mid flood tide), showing the surface wastewater plume extending east/onshore (to the right) from the outfall. Note the presence of the north-south trending foam line.

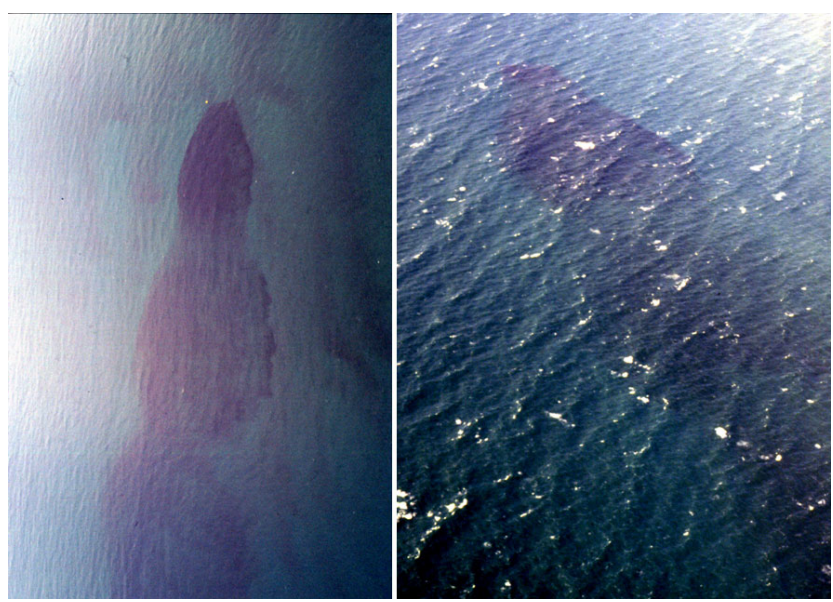

Fig. 4. a (left panel). Oblique aerial photograph, obtained on 29 April 2001 (end of ebb tide), showing the surface wastewater plume extending south/alongshore (to the bottom) from the outfall. b (right panel). Oblique aerial photograph, obtained on 29 April 2001 (flood tide), showing the surface wastewater plume extending southeast from the outfall. Note the white capping of waves caused by the strong wind.
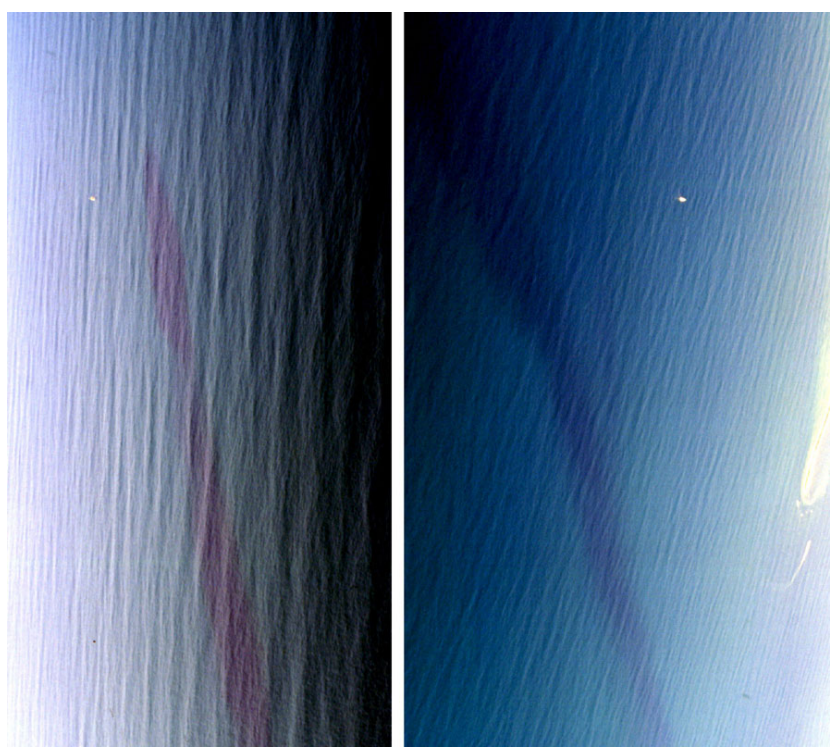

Fig. 3. a (left panel). Oblique aerial photograph, obtained on 27 September 2000 (flood tide), showing the surface wastewater plume extending south/alongshore (to the bottom) from the outfall. b (right panel). Oblique aerial photograph, obtained on 8 September 2001 (flood tide), showing the surface wastewater plume extending south/ alongshore (to the bottom) from the outfall. Note the breakwaters delimiting the inlet channel on the right centre of the image.
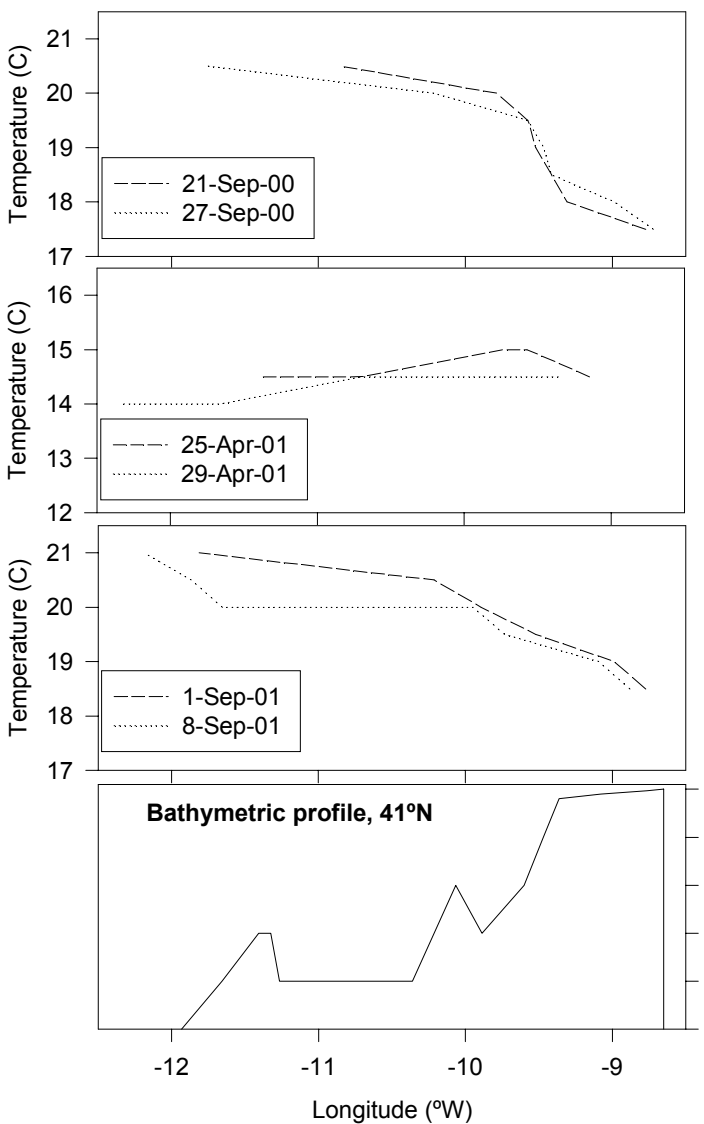

Fig. 5. Graphs of sea surface temperature along the $41^{\circ} \mathrm{N}$ parallel over the continental shelf, slope and deep ocean (shown on the bathymetric profile). 


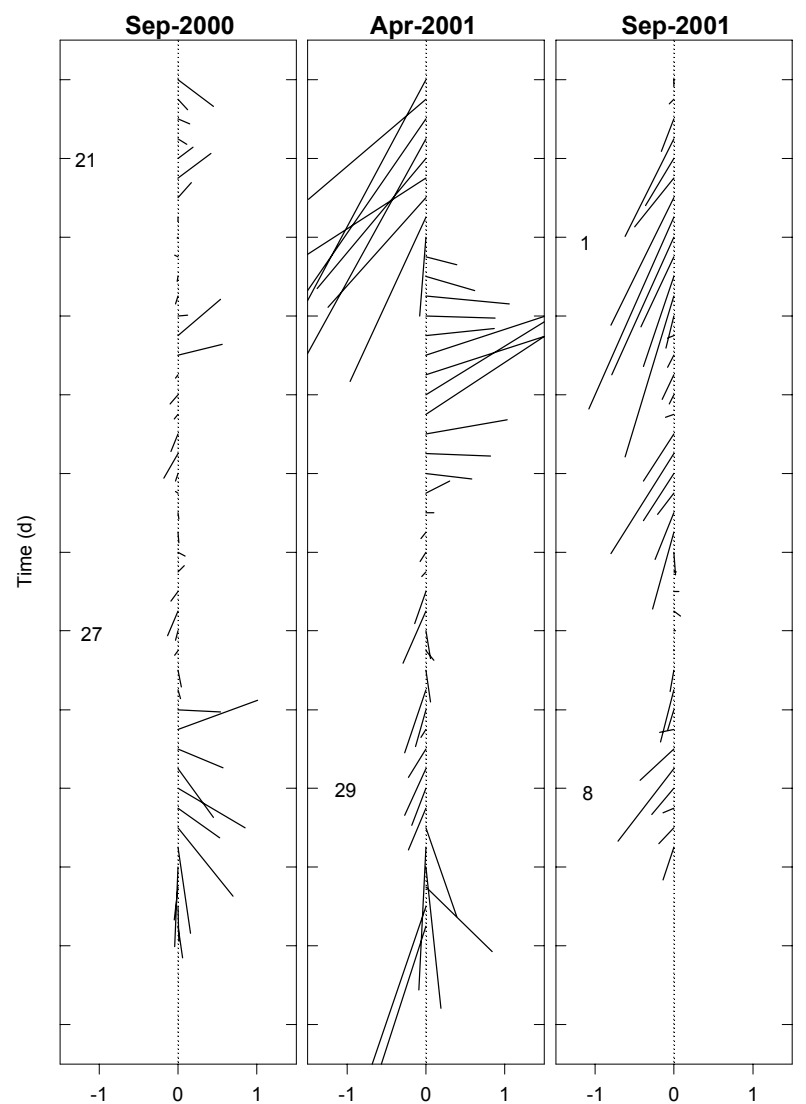

Fig. 6. Time series graphs of vectors for the surface layer transport, taken at $45^{\circ}$ to the right of the wind direction. The length of vectors is proportional to the surface layer transport $\left(\mathrm{m}^{3} \mathrm{~s}^{-1} \mathrm{~m}^{-1}\right)$. The direction of vectors is relative to the direction of the coast (dotted) line, offshore to the left, onshore to the right.

the terms of the EEC Urban Waste-Water Treatment Directive (91/271/EEC), Portugal has designated its entire west coast as a 'less sensitive area' but the Ria de Aveiro has been designated as a 'sensitive area' in terms of eutrophication. The observations described above suggest that the eutrophication of the Ria de Aveiro is unlikely to change as a result of the operation of the submarine outfall, which had as its objective to reduce the nutrient loading to the lagoon. Furthermore, this study demonstrates how simple observations of wastewater discharge from a submarine outfall can improve understanding of nearshore circulation.

\section{Acknowledgements}

The authors gratefully acknowledge the assistance of Bruce McKenzie of the US Naval Oceanographic Office, Lynn deWitt of the US Pacific Fisheries Environmental Laboratory, the aircraft pilot António Carneiro and the Aeroclube de Aveiro. This work was supported financially by Saneamento Integrado dos Municípios da Ria, SA (SIMRIA).

\section{References}

Álvarez-Salgado, X.A., Gago, J., Míguez, B.M., Gilcoto, M. and Pérez, F.F., 2000. Surface waters of the NW Iberian margin: upwelling on the shelf versus outwelling of upwelled waters from the Rías Baixas. Estuar. Coast. Shelf Sci., 51, 821-837.

Capitão, R., Fortes, C.J., Carvalho, M.M. and Covas, J.A., 1999. Definição de Regimes de Agitação Marítima - Casos de Estudo. In: AIPCN-PIANC, $1^{a}$ S Jornadas Nacionais de Engenharia Costeira e Portuária. Porto, Novembro de 1999, 31-45.

Ferreira, O.M.F.C., 1993. Caracterização dos principais factores condicionantes do balanço sedimentar e da evolução da linha de costa entre Aveiro e o Cabo Mondego. Tese de Mestrado, Universidade de Lisboa, $166 \mathrm{pp}$.

Frouin, R., Fiúza, A.F.G., Ambar, I. and Boyd, T. J., 1990. Observations of a poleward surface current off the coasts of Portugal and Spain during winter. J. Geophys. Res., 95, 679691.

Gómez-Gesteira, M., deCastro, M., Prego, R. and Pérez-Vilar, V., 2001. An unusual two layered tidal circulation induced by stratification and wind in the Ría of Pontevedra (NW Spain). Estuar. Coast. Shelf Sci., 52, 555-563.

Haynes, R., Barton, E.D. and Pilling, I., 1993. Development, persistence, and variability of upwelling filaments off the Atlantic coast of the Iberian peninsula. J. Geophys. Res., 98, 22681-22692.

Hopkins, T.S. and Swoboda, A.L., 1986. The nearshore circulation off Long Island - August 1978. Cont. Shelf Res., 5, 431-473.

Niedoroda, A.W., Swift, D.J.P., Hopkins, T.S. and Ma, C.-M., 1984. Shoreface morphodynamics on wave dominated coasts. Mar. Geol., 60, 331-354.

Silva, J.F., Duck, R.W., Anderson, J.M., McManus, J. and Monk, J.G.C., 2001. Airborne observations of frontal systems in the inlet channel of the Ria de Aveiro, Portugal. Phys. Chem. Earth (B), 26, 713-719.

Silva, J.F., Duck, R.W., Hopkins, T.S. and Rodrigues, M., 2002. Managing the nutrient inputs to a coastal lagoon: the case of the Ria de Aveiro, Portugal. Hydrobiologia, 475, 379-385.

Sordo, I., Barton, E.D., Cotos, J.M. and Pazos, Y., 2001. An inshore poleward current in the NW of the Iberian Peninsula detected from satellite images, and its relation with $G$. catenatum and $D$. acuminata blooms in the Galician Rias. Estuar, Coast. Shelf Sci., 53, 787-799

Sousa, F.M. and Bricaud, A., 1992. Satellite-derived phytoplankton pigment structures in the Portuguese upwelling area. J. Geophys. Res., 97, 11343-11356. 